\title{
Latin American Philosophers: Some Recent Challenges to Their Intellectual Character*
}

\author{
Susana NuCCeTELli
}

Philosophy Department, CH 365M

St. Cloud State University

St. Cloud, MN 56301

sinuccetelli@stcloudstate.edu

\begin{abstract}
Why hasn't Latin American philosophy produced any internationally recognized figure, tradition, or movement? Why is it mostly unknown inside and outside Latin America? Some skeptical answers to these questions have recently focused on critical-thinking competences and dispositions. Latin American philosophers are said to lack, for example, originality in problemsolving, problem-making, argumentation, and to some extent, interpretation. Or does the problem arise from their vices of "arrogant reasoning?" On my view, all of these answers are incomplete, and some even self-defeating. Yet they cast some light on complex, criticalthinking virtues and vices that play a significant role in philosophical thinking.
\end{abstract}

Résumé: Pourquoi la philosophie latino-américaine n'a-t-elle pas produit un personnage, une tradition ou un mouvement reconnu internationalement? Pourquoi est-elle généralement inconnue à l'intérieur et l'extérieur de l'Amérique latine? Quelques réponses sceptiques à ces questions ont récemment mis l'accent sur les compétences de pensée critique et dispositions. On dit que les philosophes d'Amérique latine manquent, par exemple, d'originalité dans leurs habiletés de résoudre et de soulever des problèmes, de construire des arguments, et dans une certaine mesure, d'interpréter des problèmes et des arguments. Ou est-ce que le problème survient de leurs vices de «raisonnement arrogant»? À mon avis, toutes ces réponses sont incomplètes et certaines sont même autodestructrices. Pourtant, elles jettent une certaine lumière sur les vertus et les vices complexes de la pensée critique qui jouent un rôle important dans la pensée philosophique.

Keywords: intellectual virtues, intellectual vices, arrogant reason, Latin American philosophy

\footnotetext{
* A Keynote address at the OSSA11 Conference: Argumentation, Objectivity and Bias, University of Windsor, May 18-21, 2016.
}

(C) Susana Nuccetelli. Informal Logic, Vol. 36, No. 2 (2016), pp. 121-135. 


\section{Susana Nuccetelli}

\section{Introduction}

For Latin American philosophers, the quality of their own philosophical work is a recurrent metaphilosophical question. An influential answer to this question has being skeptical. Its arguments point at some invisibility problems facing Latin American philosophy, allegedly the product of its practitioners' deficiency in certain intellectual virtues. On this view, successful philosophical theorizing requires a sufficient degree of various kinds of originality, as well as other good traits of intellectual character to be explored here. I first outline skepticism of this sort. Then I show that, although it faces objections of its own, it also provides evidence of the existence of a Latin American philosophical tradition that makes a significant contribution to a rarely explored area of critical thinking: namely, that of the complex intellectual virtues that can promote, and related vices that can hinder, disciplinary development. By doing so, this tradition opens the way to a novel approach to some invisibility problems facing also other underrepresented areas of philosophy.

\section{Two invisibility problems for Latin American philosophy}

At the beginning of the twenty-first century, a new wave of skeptics has reignited a mid-twentieth-century debate about the quality of Latin American philosophy. Like the old skeptics, the new ones acknowledge that philosophy exists in Latin America as a discipline and profession autonomous from science, theology, literature, politics, education, and other disciplines or practices. They also acknowledge that philosophy in the region meets current Western standards of proper representation in educational systems, learned societies, associations, journals, presses, etc. Their criticism concerns instead some criticalthinking vices of its practitioners that they regard as responsible for the problems facing Latin American philosophy considered below.

For now, note that intellectual character, together with cognitive skills, is indeed a building block of critical thinking according to the Delphi Report (Facione 1990). Issued by an interdisciplinary panel with the goal of characterizing critical thinking and determining how it can be taught, the Delphi Report nonetheless fell short of identifying a set of intellectual virtues that are conducive to successful disciplinary development and a set of vices that may hinder that development. It thus left a gap that the skeptical work about the quality of Latin American 
philosophy may be regarded as closing — or at the very least, I'll be arguing, as a step in the right direction - since it advances the understanding of what those virtues and vices are.

Before showing how it does that, some clarification points are in order. By 'virtue' and 'vice' in this context I mean traits of intellectual character that have, besides an "affective" component as pointed out in the Delphi Report, certain behavioral, motivational, and intellectual components. Thus, a virtuous intellectual agent is not only one who has, for example, taught herself to think in accordance with sound inference. In addition she does so for the appropriate reason and out of the appropriate motivation and feeling. She regards soundness in inference as something good, aims at it, and is disposed to disapprove of anyone making unsound inferences. Given the new skepticism, Latin American philosophers lack certain critical-thinking virtues whose absence in fact amounts to intellectual vices. On their view, these explain why the discipline in the region faces two invisibility problems:

External Invisibility (EI) - Those working in Western centers of philosophy do not regularly consider contributions by Latin American philosophers.

Internal Invisibility (II)_Latin American philosophers do not regularly consider contributions by other Latin American philosophers.

I'll consider the evidence for the existence of these problems in Section III, after having a closer look at the critique of Latin American philosophy offered by some predecessors of the new skeptics.

\section{Early metaphilosophical skepticism}

The claim that Latin American philosophers perform poorly compared to their peers in countries that are producers of philosophy has been familiar since the mid-twentieth century. I call that early version of the claim 'Old Skepticism' and summarize it as follows:

Old Skepticism (OS): At most, only a very small part of Latin American philosophy is of any value.

One of the first supporters of OS was Brazilian analytic philosopher Euryalo Cannabrava, who in 1949 arrived at this thesis by 


\section{Susana Nuccetelli}

comparing philosophy in the Americas. His critique of Latin American philosophy focused on the cognitive-skills dimension of its practitioners, finding their reasoning affected by sophistry and a kind of literary thinking far remove from the strict rules followed so closely by North American philosophers. Consistent with this assessment is Cannabrava's explanation of the reception of continental philosophy in Latin America, which at the time meant mostly contemporary offshoots of German idealism construed broadly to include phenomenology and incipient existentialism. Cannabrava believed that Latin American philosophers were attracted to continental philosophy precisely because of its "lack of intelligibility," and "its metaphysical abuses and frequent violation of the rules of correct thinking" (1949, p. 114). He held that Latin American philosophy was at its worst when addressing issues in philosophy of science, a judgment supported by evidence from the Mexican philosopher Antonio Caso's writings on science. On Cannabrava's view, they exhibited a complete lack of "real acquaintance with [science's] development or technique" (1949, p. 117). All of these shortcomings led Cannabrava to lament that "[i]n Latin America we do not have philosophers like Morris Cohen, Victor Lenze, Ernest Nagel, and F. S. C. Northrop, who have studied the sources of science and followed closely its development..." (1949, p. 117).

Cannabrava's conclusion, a form of OS, combines the factual with the evaluative. For in its context, it goes beyond stating that Latin America lacks internationally recognized philosophers: it suggests that there is something wrong with it. In order to explain what that is, Cannabrava appeals to factors concerning the origins and history of the discipline, including its development in connection with literature and the arts, where precise reasoning and linguistic clarity are intentionally avoided. By contrast, in the English-speaking world, philosophy developed in connection with the formal and the empirical sciences, where precise reasoning and clear language are important values.

Be that as it may, other twentieth-century Latin America philosophers also endorsed OS but for different reasons. On their view, the main problem facing philosophy in the region was neither the lack of sound reasoning nor the lack of linguistic clarity but rather the lack of originality. In 1949, Argentinian Risieri Frondizi made an influential attempt at showing that this problem was indeed pervasive. After analyzing the evidence for a report on Latin American philosophy commissioned by the US Library of Congress, Frondizi claimed that only $10 \%$ of academic philosophy in Latin America was original in the sense of having original theories and methods as well as creative practitioners. Although, like Cannabrava, Frondizi endorsed a version of 
the OS, his reason for this thesis is properly called 'originalism' because it demands that, to be of value, a philosophy must be original (Gracia 2003).

Originalism, which together with the empirical evidence about Latin American philosophy analyzed by Frondizi entails the OS claim, has been a popular view among twentieth century Latin American skeptics - not only among analytic philosophers and phenomenologists but also among Marxists and others. In fact, as early as 1925 Peruvian José Carlos Mariátegui expressed a similarly bleak view of Latin American philosophy grounded in deterministic reasoning. He argued for OS from a factual premise about the cultural and economic dependence of Latin America upon Europe and the assumption that no region can have interesting philosophy unless it has achieved independence on both counts. In 1968, Peruvian Augusto Salazar Bondy offered a more sophisticated Marxist argument along the lines suggested by Mariátegui. I have shown the vulnerability of this line of argument elsewhere (see Nuccetelli 2003). But more needs to be said against the skeptical claim OS, since it is undeniable that philosophy in the region at the very least lacks the international recognition of the discipline in Western centers held crucial by Cannabrava. What, if anything, is wrong with it?

For originalists the answer was to be found in its practitioners' poor score in the virtue of originality. Accordingly, they took pains to analyze the virtue of originality. In 1968, Salazar Bondy published a small but influential book devoted chiefly to that analysis. It provides a meticulous conceptual clarification of this intellectual virtue, which he distinguishes from other virtues that might be relevant to the success of philosophical development. Putting together his analysis with the views of other participants in the skeptical debate at the time, it emerges that

1. Originality is the virtue of theorists whose works are creative, in the sense of being novel;

2. Authenticity is the virtue of theorists whose works are genuine, in the sense of being non-spurious; and

3. Peculiarity is the virtue of theorists whose works are autochthonous, in the sense of being related to a certain region (e.g., Latin America). ${ }^{1}$

Of all these, (1) is the most relevant to the old skeptic's claim OS. As evident in their philosophical works, having (3) is neither necessary nor sufficient for having (1). Having (2) is neces-

\footnotetext{
${ }^{1}$ For textual evidence about the views of Salazar Bondy and other skeptics of the time, see Nuccetelli 2013.
} 


\section{Susana Nuccetelli}

sary though not sufficient for having (1). An author of a work that is imitative or the product of plagiarism would lack (2) and therefore also (1). And a work that, by being genuine, has (2) may lack (1) if the author fails to be creative, and also (3) if she or her topic is not related in some relevant sense to Latin America. Having (1) is neither necessary nor sufficient for (3), and sufficient but not necessary for (2). More recently, Mexican philosopher Guillermo Hurtado (2007) and other new skeptics have added to the list,

4. Being tradition-generating - the virtue of theorists whose works become a paradigm for subsequent philosophical work.

As virtues of philosophers, it is obvious that (1) through (4) are in each case a matter of degree. With that in mind, it is also obvious that, except for (3) and (4), lacking (1) and (2) to a significant degree amounts to having vices - namely, the vices of being unoriginal and inauthentic, respectively.

Mexican philosopher Leopoldo Zea led the 'distinctivist' reaction to originalism according to which, since the works of Latin American philosophers are evidence of their having peculiarity (virtue 3), old skepticism must be false. Given this argument, peculiarity is sufficient for originality (1), which in turn does not require authenticity (2). ${ }^{2}$ Yet there is no good reason for thinking that peculiarity entails originality. After all, as defined above, 'peculiarity' may be a purely descriptive concept while 'originality' is usually a term of praise expressing what ethicists would call a 'thick concept' that is at once both descriptive and evaluative. Any work whose author is Latin American would show peculiarity, but nothing follows about its being original, authentic, or tradition-generating.

So skeptics can resist the distinctivist reply and invoke the above analysis to run this charge:

Skeptical Normative Charge (SNC): Latin American philosophy has made no substantial contribution to philosophy, as a result of its practitioners' lacking a significant degree of originality, authenticity, and the capacity for being tradition-generating.

\footnotetext{
${ }^{2}$ Distinctivists plausibly argue that Latin American philosophy has peculiarity because its practitioners mostly come from a Latin American context. But then they make the doubtful claim that peculiarity entails originality, something that Latin American philosophy will eventually develop "por añadidura" (i.e., in addition). Furthermore, on their view, (2) is irrelevant to this debate. See for example Zea 1991 and my 2003 objections to his argument.
} 


\section{Recent metaphilosophical skepticism}

To substantiate the SNC, the new skeptics invoke evidence for the internal and external invisibility problems mentioned above. Internal invisibility (II), the problem that Latin American philosophers do not intellectually engage with each other, relies mostly on the skeptics' personal experiences and surveys of professional publications. External invisibility EI, the problem that that producers of philosophy ignore Latin American philosophers, is similarly supported by evidence that is partly anecdotal and partly based on analysis of publications. Thus to show that the II problem arises, Pereda (2003) invokes data from the Enciclopedia iberoamericana de filosofia, a Spanish collective publication whose first volume appeared in 1987, and in whose volumes devoted to general subjects there is a noticeable absence of references to Latin American and Spanish authors. To show that the EI arises, Hurtado (1999) invokes data from the 1998 Routledge Encyclopedia of Philosophy showing the underand mis-representation of Latin American philosophy in the English-speaking world. The II and EI problems for Latin American philosophers are good reasons for accepting the skeptical normative charge. It is important, then, to consider the reasons for thinking that these problems do arise. For Carlos Pereda (2003), they arise because of Latin American philosophers' intellectual vices of "arrogant reasoning." Here we need to assume that Pereda is making a non-universal generalization, since otherwise Pereda himself (among other new skeptics) would suffer from such vices, which would make his diagnosis selfdefeating. ${ }^{3}$ The vice-affected philosophers targeted by Pereda may be either distinctivist or universalist. As we saw, distinctivists hold that philosophical writings always show the local perspective of their authors (i.e., they are always evidence of peculiarity). Universalists deny this. Consequently, the vices of arrogant reasoning characterize each of these stances:

\footnotetext{
${ }^{3}$ Plainly, if Pereda's work is seriously affected by intellectual vices, then why should we accept his argument? To avoid this objection, he needs to restrict the scope of his skeptical claim.
}

(C) Susana Nuccetelli. Informal Logic, Vol. 36, No. 2 (2016), pp. 121-135. 


\begin{tabular}{|l|l|l|}
\hline & $\begin{array}{l}\text { Main claim about the } \\
\text { nature of Latin Ameri- } \\
\text { can philosophy }\end{array}$ & $\begin{array}{l}\text { Main intellectual } \\
\text { vices }\end{array}$ \\
\hline Distinctivists & $\begin{array}{l}\text { Perspectivism: } \\
\text { Latin American phi- } \\
\text { losophers always con- } \\
\text { sider universal prob- } \\
\text { lems and theories } \\
\text { with a local lens }\end{array}$ & $\begin{array}{l}\text { National } \\
\text { enthusiasm }\end{array}$ \\
\hline Universalists & $\begin{array}{l}\text { A denial } \\
\text { of perspectivism }\end{array}$ & $\begin{array}{l}\text { Subaltern fervor, } \\
\text { Craving for novelty }\end{array}$ \\
\hline
\end{tabular}

As defined by Pereda, the nationalist enthusiasm that affects distinctivists is the result of their taking decolonization to an extreme, as illustrated by the distinctivists' reluctance to study major Western figures such as Aristotle or Frege and emphasis on the need to focus on works that are "theirs" (i.e., regional). Subaltern fervor is the vice of universalists because they invariably assume that the right philosophical view must come from elsewhere. They also suffer from the vice of craving for novelty, which is present when intellectual curiosity, which is generally a virtue, is brought to an extreme and becomes an incontrollable impulse for being up-to-date. At that point, knowledge ceases to be the aim of inquiry.

Pereda (2003, p. 67) contrasts these vices of philosophers with the virtues of Latin American essayists, who since the early days of the Iberian Conquest produced a hybrid genre with elements of philosophy, politics, literature, and the sciences. Their work has enjoyed (and still does) internal and external visibility. Althought Pereda supports his claim by invoking mostly contemporary essayists, early figures such as Bartolomé de las Casas, Juana Inés de la Cruz, Simón Bolívar, and José Martí can also be invoked to argue that the Latin American essayists had intellectual virtues that could help philosophers. For Pereda, they consist in

1. Freshness ("Frescura"): The virtue of approaching a problem from a new angle; breaking with the past; aiming at surprising.

2. Particularity ("Particularidad"): The virtue of starting out with sufficiently described specific cases.

3. Publicity ("Publicidad"): The virtue of addressing nonexperts; avoiding jargon.

4. Interpellation ("Interpelación"): The virtue of aiming mostly at persuasion, not at informing. 
In line with Pereda's diagnosis is that of Argentinean philosopher Eduardo Rabossi (2003, 2008). According to Rabossi, the Latin American philosopher is, above all, a periphery thinker with the self-image of a 'guacho' (a homeless orphan, a street urchin) who not only fails to acknowledge his own "philosophical parents," but does not want to know about them at all. As Rabossi puts it, the Latin American philosopher "doesn't take them into account, he doesn't read them, he is not even interested in criticizing their defects or limitations; for him, his own philosophical past doesn't exist" (2008: 103, my translation). Lacking awareness of their own philosophical past and unwilling to establish dialogue with local peers, Latin American philosophers can have neither philosophical traditions nor genuine philosophical communities. The typical vices of these periphery philosophers can be classified in two categories,

Category I: Vices Amounting to Individual "Tics"

Philosophical orphanhood (guachidad filosófica), or the systematic neglect of local traditions

Acritical adoption of an area, school, or thinker from a philosophical center

Compulsion to import philosophy without developing local traditions

Tendency to conflate the practice of philosophy with that of advocacy

Category II: Vices Amounting to Bad "Manners" of Professional Interaction

Biased attitude against works and persons (as manifested in a tendency to disqualify works out-of-hand by claiming that they are not philosophy, they are bad philosophy, etc.

Refusal to learn about the work of others

Avoidance of authentic dialogue with each other

Besides Pereda and Rabossi, Hurtado has made another attempt at spelling out the vices of Latin American philosophers, which he regards as analogous to the vices of Mexican philosophers (2006: 206 ff.; 2007: 24 ff.). On his view, by adopting a "modernizing model" of philosophy, philosophers of the region have developed bad traits of intellectual character, including a proclivity to form small groups and spend most of their time trying to learn some imported philosophy, citing only foreign philosophers without paying much attention to regional peers. Modernizers compulsively adopt the latest tradition after uncrit- 


\section{Susana Nuccetelli}

ically replacing previous traditions when they deem them unfashionable. At the end of the day, in Latin American philosophy "...each modernizing movement got lost for the upcoming movement..." (Hurtado 2006, p. 206), leaving in place neither traditions nor stable communities of inquiry. "But the foreign philosophers," laments Hurtado, "even those who visit our countries to deliver talks, very rarely quote us in their work. There is therefore no genuine dialogue..." (Hurtado 2006, p. 205). Like Pereda and Rabossi, Hurtado too draws a skeptical conclusion from anecdotal evidence about these philosophers' vices and seems to think that Latin American philosophy's II problem is more pressing than its EI problem.

Mexican new-skeptic Maite Ezcurdia (2003) disagrees. On her view, it is rather the EI problem that must be fixed first. If most Latin American philosophers do in fact work within a modernizing model, it is likely that they would be motivated to consider their peers' works only after some of these works have acquired international recognition. So Ezcurdia contends that fixing the EI problem is bound to resolve eventually the II problem. Be that as it may, Ezcurdia fully endorses the normative skeptical charge (NSC), which she thinks is supported by the Latin American philosophers' low scores in certain kinds of originality. She distinguishes four kinds of originality resulting from four non-overlapping virtues of philosophers anywhere: interpretative, argumentative, problem-making, and problemsolving originality. Since Latin American philosophers have on the whole been successful at interpreting the works of philosophers from the major centers of the West, their works exhibit the virtue of interpretative originality to a significant degree. But she finds them lacking in originality of the other three kinds. Ezcurdia's brief diagnosis of these problems for Latin American philosophy quickly leads to a recommendation about how to fix its EI and II problems: namely, by means of fostering originality of the other three types. In particular, an improvement in problem-solving originality is needed.

\section{What is wrong with metaphilosophical skepticism?}

There are, however, reasons to think that given these arguments for metaphilosophical skepticism, any attempts to fix the II and EI problems for Latin American philosophy are likely to be futile. For one thing, by all counts, most of its practitioners are universalists. If Pereda, Rabossi, Hurtado, and Ezcurdia are right about their vices, then there are a vast number of Latin American philosophers who suffer from subaltern fervor, craving for 
novelty, philosophical guachidad, adherence to a modernizing model of philosophy, etc. Since per force those philosophers devote considerable time and effort to assimilating the latest fads coming from France or the US, they are hardly free to devote themselves to reforming their intellectual characters and producing work that is original to a significant degree. Such activities would require motivation, time, and effort that universalists lack. After all, they are too busy learning and abandoning different Western traditions, replacing old fads with new ones that they try to assimilate, only to abandon them in short order and begin all over again. (I was once told that there is a new fad in philosophy every ten years!) Thus there seem to be empirical constraints for the Latin American universalists to following the new skeptics' recommendations for improving their intellectual character. ${ }^{4}$

Furthermore, the new skeptics' position is vulnerable to the following, non-fallacious ad hominem: their recommendations run into the same II and EI problems they are trying to fix, namely, the lack of dialogue between philosophers inside Latin America and between these and their peers in North America. For one thing, the new skeptics never engage with, or at any rate acknowledge, the arguments and subtle conceptual distinctions of the old skeptics (which include many others besides Cannabrava, Salazar Bondy, and Frondizi). References to skepticism about Latin American philosophy by new skeptics, when included, are limited to their own work. For example, a notable absence in Ezcurdia's discussion of originality is Salazar Bondy's subtle analysis of this virtue and its relevance to philosophy. Furthermore, although there is a great deal of overlap among the new skeptics' own recommendations, with a few exceptions they neither acknowledge each other's works nor explicitly join forces to maximize their chances of being tradition-generating. In addition, the new skeptics invariably ignore the contributions to the debate from Latin American philosophers in Europe and North America. Cases in point are Jorge Gracia's (2003) argument that originalism makes an unreasonable demand on any kind of philosophy and his conception of Latin American philosophy as an ethnic philosophy, and my own proposal (Nuccetelli 2003, 2013) to consider the discipline a branch of applied philosophy.

\footnotetext{
${ }^{4}$ To my knowledge, Rabossi made no such recommendation. But his critique is consistent with the recommendations by other new skeptics, in particular Hurtado's. According to this, the II can get resolved if "we create a genuine critical dialogue among ourselves and simultaneously exercise a constantly renewed memory of past dialogues" (2006, p. 210).
} 


\section{Susana Nuccetelli}

Finally, note that by reviving in fact what is an already existing skeptical view about the nature of Latin American philosophy, the new skeptics are a counterexample to the claim that Latin American philosophers fail to be tradition-generating. After all, works like the present essay show that there is already in Latin America at least one philosophical tradition of the very sort these skeptics claim the region lacks. This metaphilosophical tradition can be traced from the beginning of the twenty-first century in the work of the new skeptics to the early twentieth century in the work of Mariátegui, Cannabrava, Frondizi, Salazar Bondy, and many others. As I'll argue next, it has produced original work on critical thinking and metaphilosophy by identifying crucial intellectual virtues and vices relevant to professional and disciplinary development.

\section{The upshot}

Both old and new skeptics charge that Latin American philosophers have a number of critical-thinking vices that show in their work and academic conduct. Some new skeptics (i.e., Pereda and Rabossi) regard them as "colonial" vices. Yet they are by no means exclusive of periphery philosophers. For example, as characterized by Rabossi philosophical orphanhood flourishes in many North American philosophy departments where the study of original sources is disparagingly labelled 'history of ideas.' Similarly, the dismissal of some philosophical views out-ofhand by declaring them "non-philosophical" or "bad philosophy" is not at all uncommon in interactions by North American philosophers.

Suppose, however, that the skeptical claim is that Latin American philosophers have a larger share of these intellectual vices compared with their peers in centers of the West. Still, they would not be alone in this, for an analogous heavy burden of similar vices may be what's interfering with the overcoming of invisibility problems in other areas of philosophy. Metaphilosophical skeptics would then have initiated a new line of reflection on the problems facing other underrepresented areas of philosophy that might lead to fruitful results.

Furthermore, the invisibility problems for Latin American philosophy, together with the intellectual vices apparently causing them, may not be as damaging as the new skeptics claim. Besides the argument for the existence of philosophical traditions in Latin America offered above, there is the evidence of growing attention to Latin American philosophy in centers of the West, where the number of publications and interest groups 
in this area has increased in the last few years. As a result, the attempt to raise an EI problem for the area solely on the basis of inaccuracies about it in some reference book such as the Routledge Encyclopedia of Philosophy (see Hurtado 1999) amounts to an ignoratio elenchi.

Most important, I submit that metaphilosophical skepticism contributes to the understanding of critical-thinking virtues that can promote, and vices that can hinder, the development of philosophy as a discipline and of individual philosophers as professionals. Although much more needs to be said, this skeptical tradition's analysis already represents progress in accounting for some relevant critical-thinking virtues and vices left out of the Delphi Report, such as
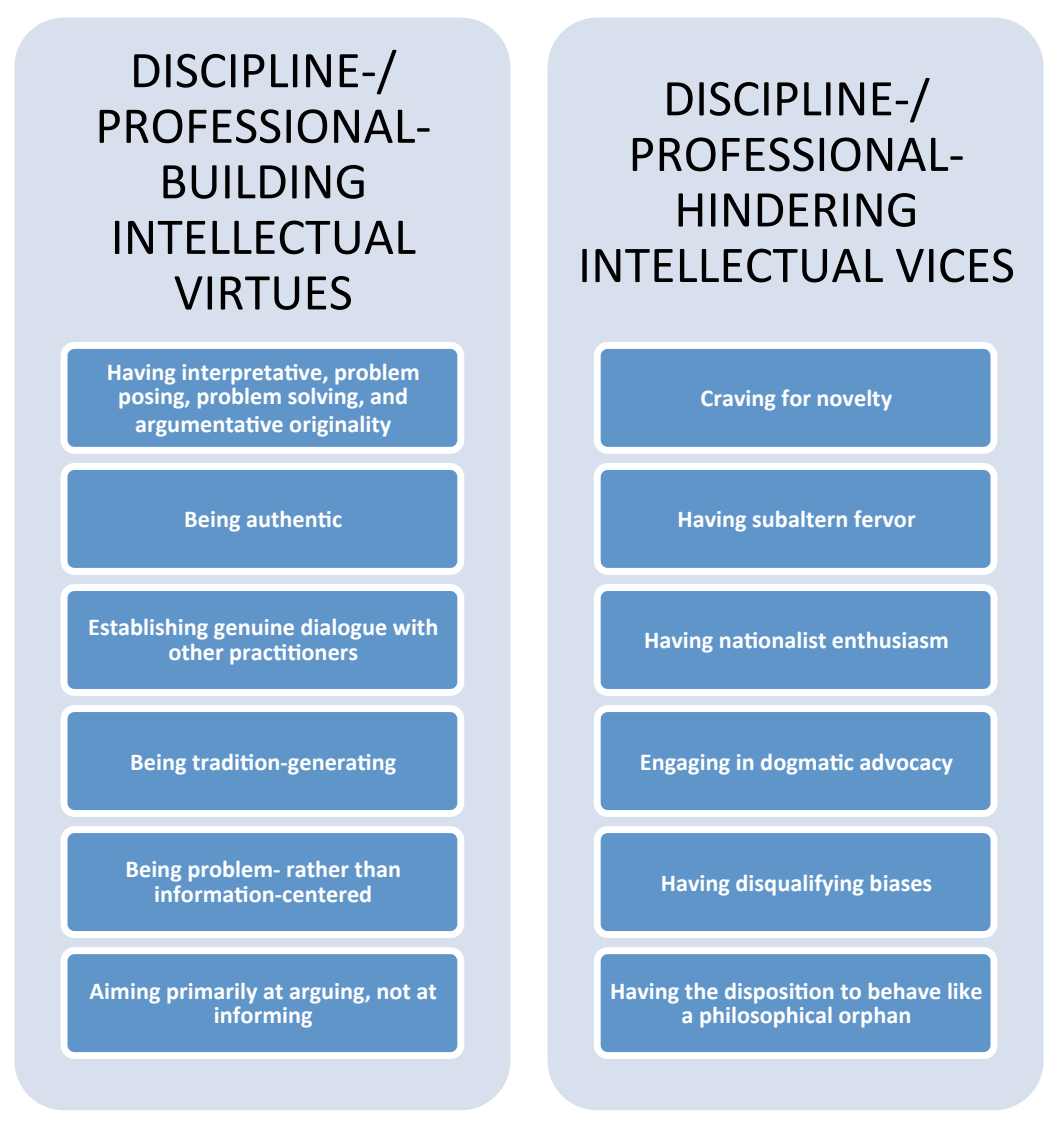

Of course the invisibility problems for Latin American philosophy still remain. Possibly, they involve more than the affective dimension of critical thinking allegedly causing them. Any complete explanation would have to consider also economic, historical, and cultural elements. Among the former is the fact that the greater wealth of private and public universities in 


\section{Susana Nuccetelli}

countries that are producers of philosophy provides their philosophers with access to libraries and other research resources that their Latin American peers lack. Furthermore, English has become the lingua franca of the academic community, as well as a barrier for many Latin American philosophers who wish to publish in Western journals or with imprints that can best promote their work in the international forum. And perhaps Cannabrava was not far off the mark after all in associating some criticalthinking dispositions of Latin American philosophers with historical and cultural contingencies concerning the development of their discipline in the subcontinent.

\section{References}

Cannabrava, Euryalo. 1949. "Present tendencies in Latin American philosophy." Journal of Philosophy 46(5): 113-119.

Craig, Edward ed. 1998. Routledge Encyclopedia of Philosophy. New York: Routledge. Ezcurdia, Maite. 2003. In La filosofía en América Latina como problema, ed. Cruz Revueltas, 196202. Mexico City: Publicaciones Cruz

Facione, Peter A. ed. 1990. Delphi Report. Critical Thinking: A statement of Expert Consensus for Purposes of Educational Assessment and Instruction. Millbrae CA: California Academic Press, URL accessed 5 April 2016:

$<$ https://assessment.trinity.duke.edu/documents/Delphi_Report.p df $\geq$.

Frondizi, Risieri. 1949. "Is there an Ibero-American philosophy?" Philosophy and Phenomenological Research 9(3): 345-355.

Gracia, Jorge J. E. 1996. "Foreword: The Origins of Hispanic Philosophy." In The History of Philosophy in Colonial Mexico, Mauricio Beuchot, xi-xxx. Washington, D.C.: The Catholic University of America Press.

Gracia, Jorge J. E. 2003. "Ethnic labels and philosophy: The case of Latin American philosophy," in Latin American philosophy: Currents, issues, debates, ed. Eduardo Mendieta, 57-67. Bloomington, IN: Indiana University Press.

Hurtado, Guillermo. 2003. "Enciclopedia de filosofia," In $L a$ filosofía en América Latina como problema, ed. Cruz Revueltas, 45-56. Mexico City: Publicaciones Cruz.

Hurtado, Guillermo. 1999. "Routledge Encyclopedia of Philosophy," Diánoia 45(45): 227-234.

Hurtado, Guillermo. 2006. "Two Models of Latin American Philosophy." Journal of Speculative Philosophy 20(3): 204213. 
Hurtado, Guillermo. 2007. El búho y la serpiente: ensayos sobre la filosofía en México en el siglo XX. Mexico City: UNAM.

Mariátegui, Jose Carlos. 1925. "Existe un pensamiento hispanoamericano?" Repertorio Americano 10(17): 113-115.

Nuccetelli, Susana. 2003. 'Is 'Latin American Thought' Philosophy?" Metaphilosophy 34(4): 524-537.

Nuccetelli, Susana. 2013. "Latin American Philosophy: Metaphilosophical Foundations." In Stanford Encyclopedia of Philosophy, ed. Edward N. Zalta, URL accessed 5 April 2016:<http://plato.stanford.edu/entries/latin-americanmetaphilosophy/>.

Pereda, Carlos. 2003. “¿Qué puede enseñarle el ensayo a nuestra filosofía? In La filosofía en América Latina como problema, ed. Juan C. Cruz Revueltas, pp. 34-44. Mexico City: Publicaciones Cruz.

Rabossi, Eduardo. 2003. "Filosofar: Profesionalismo, profesionalidad, tics, y modales." In La filosofía en América Latina como problema, ed. Juan C. Cruz Revueltas, pp. 3444. Mexico City: Publicaciones Cruz.

Rabossi, Eduardo. 2008. En el comienzo Dios creo el canon: Biblia berolinensis, ensayos sobre la condición de la filosofía. Buenos Aires: Gedisa.

Romero, Francisco. 1944. "Sobre la filosofía en Iberoamérica." In Filosofía de la persona y otros ensayos, ed. Francisco Romero, 147-157. Buenos Aires: Losada.

Salazar Bondy, Augusto. 1968. ¿Existe una filosofia de nuestra América? Mexico City: Siglo XXI.

Zea, Leopoldo. 1991. La filosofía como compromiso de liberación. L. Caracas: Biblioteca Ayacucho. 